\title{
Caso Gómez Virula y otros vs. Guatemala
}

Sentencia de 21 de noviembre de 2019

El 21 de noviembre de 2019 la Corte Interamericana de Derechos Humanos (en adelante "la Corte" o "este Tribunal") dictó sentencia mediante la cual declaró responsable internacionalmente a Guatemala por la violación de los derechos a las garantías judiciales y protección judicial de Alexander Yovany Gómez Virula, Antonio Gómez Areano y Paula Virula Dionicio.

Por otro lado, la Corte concluyó que el Estado no violó el derecho a la vida, a la integridad personal, la libertad personal y libertad de asociación del señor Gómez Virula, ni el derecho a la integridad personal de Antonio Gómez Areano y Paula Virula Dionicio.

\section{Hechos}

Alexander Yovany Gómez Virula tenía veintidós años al momento de su desaparición el 13 de marzo de 1995. Trabajaba en la empresa RCA y era miembro del Consejo Consultivo del sindicato de dicha empresa. El sindicato de RCA se encontraba en conflicto con la empresa tras el cierre de sus operaciones. Este sindicato se encontraba afiliado a la Unión Sindical de Trabajadores de Guatemala (en adelante Unsitragua).

El 13 de marzo de 1995, el señor Gómez Virula fue visto por última vez por un compañero del sindicato. El 13 y el 14 de marzo, los padres del señor Gómez Virula, Antonio Gómez Areano y Paula Virula Dionicio, buscaron a su hijo en la Policía Nacional, centros de detención, hospitales y la morgue. El 14 de marzo de 1995, el señor Gómez Areano denunció la desaparición de su hijo ante el Procurador de los Derechos Humanos y posteriormente ante la Subjefatura del Departamento de Investigaciones Criminológicas de Guatemala. Asimismo, los días 15, 16 y 17 de marzo de 1995, la Unsitragua emitió una comunicación a la 
opinión pública y dos telegramas urgentes dirigidos al Ministerio de Gobernación, manifestando su preocupación por la posible relación entre la desaparición del señor Gómez Virula y su participación en el sindicato de la empresa RCA.

Entre el 16 y 17 de marzo de 1995, la policía hizo algunas diligencias para investigar la desaparición del señor Gómez Virula. El 19 de marzo de 1995, fue hallado el cuerpo del señor Gómez Virula en la zona 18 de la ciudad de Guatemala.

Entre marzo y el agosto de 1995, se recibieron diversas declaraciones y se hicieron otras diligencias para investigar la muerte de la víctima. El 20 de agosto de 1996, el Ministerio Público solicitó la clausura del procedimiento, y el 7 de mayo de 1997 requirió el archivo de la causa. El 6 de junio de 1997, el Sexto Juzgado de Primera Instancia Penal, Narcoactividad y Delitos contra el Ambiente emitió un auto en respuesta a lo solicitado por el Ministerio Público, manifestando que le correspondía al Ministerio Público el archivo del caso, sin necesidad de autorización judicial. A pesar de haberse solicitado al Estado, no consta en el expediente la decisión del Ministerio Público de archivar el caso.

\section{Excepción preliminar de falta de agotamiento de los recursos internos}

La Corte desestimó la excepción preliminar interpuesta por Guatemala, estableciendo que los alegatos del Estado presentados ante la Comisión no fueron claros sobre cuál era el recurso que debió agotarse.

\section{Fondo}

A. Alegado incumplimiento del deber de prevenir violaciones a los derechos a la libertad personal, integridad personal, a la vida y libertad de asociación.

La Corte recordó que en el presente caso no existían elementos para establecer que la desaparición y muerte del señor Gómez Virula fue realizada por agentes 
estatales. La controversia fue planteada únicamente respecto al alegado incumplimiento de la obligación del Estado de garantizar dichos derechos, por no haber prevenido su violación.

La Corte aclaró que, a fin de establecer un incumplimiento del deber de prevenir violaciones a los derechos a la vida e integridad personal, debe verificarse que: i) las autoridades estatales sabían, o debían haber sabido, de la existencia de un riesgo real e inmediato para la vida o integridad personal de un individuo o grupo de individuos determinado, y que ii) tales autoridades no adoptaron las medidas necesarias dentro del ámbito de sus atribuciones que, juzgadas razonablemente, podían esperarse para prevenir o evitar ese riesgo. Este estándar ha sido aplicado por la Corte, por ejemplo, en situaciones de desaparición de mujeres ocurridas dentro de un contexto de aumento de violencia homicida contra mujeres, e igualmente sería aplicable dentro de un contexto de aumento de violencia homicida contra sindicalistas. Sin embargo, en el presente caso no se demostró que el Estado supiese o debiese haber sabido que existiera una situación de riesgo real e inminente en contra de los sindicalistas con anterioridad a la denuncia de la desaparición del señor Gómez Virula.

En consecuencia, la Corte consideró que el Estado no incumplió con su deber de garantizar los derechos a la vida, a la integridad personal y la libertad personal del señor Gómez Virula. Tomando en cuenta lo anterior, el Tribunal consideró que el Estado no violó el derecho a la libertad de asociación del señor Gómez Virula.

\section{$B$. Derechos a las garantías judiciales, y protección judicial en relación con la obligación de respetar los derechos y el deber de adoptar disposiciones de derecho interno}

La Corte concluyó que el Estado: (i) no actuó con la debida diligencia para investigar la desaparición de la víctima, a pesar de que sabía que era un líder de un sindicato que se encontraba en conflicto con su lugar de trabajo; (ii) una vez hallado el cuerpo, tampoco actuó con la debida diligencia necesaria para 
preservar la escena del delito, hacerse de elementos probatorios durante las primeras diligencias, y la autopsia no demuestra que se haya realizado un estudio riguroso del cadáver; (iii) no agotó las líneas de investigación de manera diligente, pues de la información disponible se desprende que no se tomaron las acciones necesarias para investigar a las posibles personas responsables, e (iv) incumplió con su obligación de investigar los hechos en un plazo razonable.

En virtud de lo anterior, la Corte concluyó que el Estado violó los derechos a las garantías judiciales y a la protección judicial, reconocidos en los artículos 8.1 y 25.1 de la Convención Americana sobre Derechos Humanos, en relación con el artículo 1.1 de la misma, en perjuicio de Alexander Yovany Gómez Virula, Antonio Gómez Areano y Paula Virula Dionicio.

\section{Alegada violación al derecho a la integridad personal de los familiares}

La Corte hizo notar que las argumentaciones sobre la alegada violación del derecho a la integridad personal de los familiares se fundamentaron en la supuesta responsabilidad estatal por la desaparición y muerte del señor Gómez Virula y la falta de investigación adecuada de los hechos. La Corte consideró que no hay responsabilidad internacional del Estado respecto al derecho mencionado, consagrado en el artículo 5 de la Convención Americana, en tanto no estableció la participación estatal en la desaparición y muerte del señor Gómez Virula y la falta de investigación de los hechos ya fue analizada dentro del capítulo relativo a la violación de los artículos 8.1 y 25.1 de la Convención Americana, en el cual fueron declaradas víctimas.

\section{Reparaciones}

La Corte ordenó al Estado: a) continuar las investigaciones que sean necesarias para determinar y, en su caso, juzgar y sancionar a los responsables de la muerte 
del señor Alexander Yovany Gómez Virula; b) investigar, aun en el supuesto que hubiese prescrito la acción penal, los hechos ocurridos al solo efecto de satisfacer el derecho a la verdad de las víctimas y de la sociedad; c) publicar la Sentencia y su resumen oficial, y d) pagar las cantidades fijadas en la Sentencia por concepto de indemnizaciones por daños materiales e inmateriales, así como el pago de costas y gastos. 